Abstract 025 Table 1

\begin{tabular}{|c|c|c|c|c|c|c|c|}
\hline $\begin{array}{l}\text { Patient } \\
\text { number }\end{array}$ & Age & Sex & $\begin{array}{l}\text { Coronary } \\
\text { disease }\end{array}$ & $\begin{array}{l}\text { CMR stress } \\
\text { perfusion }\end{array}$ & $\begin{array}{l}\text { FFR pre } \\
\text { PCI }\end{array}$ & $\begin{array}{l}\text { FFR post } \\
\text { PCI }\end{array}$ & Outcome \\
\hline 1 & 65 & $\mathrm{~F}$ & Minor & $\mathrm{N} / \mathrm{A}$ & $\mathrm{N} / \mathrm{A}$ & & Medical \\
\hline 2 & 77 & $M$ & $\begin{array}{l}\mathrm{LAD} \\
\mathrm{Cx}\end{array}$ & $\begin{array}{l}\text { Negative } \\
\text { Negative }\end{array}$ & $\mathrm{N} / \mathrm{A}$ & & Medical \\
\hline 3 & 71 & $M$ & $\mathrm{RCA}$ & $\mathrm{N} / \mathrm{A}$ & & & PCI RCA \\
\hline 4 & 76 & $\mathrm{~F}$ & LAD & Positive & 0.68 & & PCI LAD \\
\hline 5 & 79 & $\mathrm{M}$ & LAD & Positive & 0.38 & 0.92 & PCI LAD \\
\hline 6 & 79 & $\mathrm{~F}$ & $\begin{array}{l}\text { LAD } \\
C x\end{array}$ & $\begin{array}{l}\text { Negative } \\
\text { Negative }\end{array}$ & $\begin{array}{l}0.73 \\
0.90\end{array}$ & 0.83 & PCI LAD \\
\hline 7 & 86 & $\mathrm{~F}$ & LAD & Scar & $\mathrm{N} / \mathrm{A}$ & & Medical \\
\hline 8 & 61 & $M$ & $\begin{array}{l}\mathrm{Cx} \\
\mathrm{RCA}\end{array}$ & $\begin{array}{l}\text { Positive } \\
\text { Negative }\end{array}$ & $\begin{array}{l}0.55 \\
0.29\end{array}$ & 0.95 & $\mathrm{PCl} C \mathrm{x}$ \\
\hline 9 & 75 & $\mathrm{M}$ & $\begin{array}{l}\text { LAD } \\
\text { Cx } \\
\text { RCA }\end{array}$ & $\begin{array}{l}\text { Negative } \\
\text { Negative } \\
\text { Negative }\end{array}$ & $\begin{array}{l}0.83 \\
0.91\end{array}$ & & Medical \\
\hline 10 & 51 & $\mathrm{M}$ & $\begin{array}{l}\text { LAD } \\
\text { Cx } \\
\text { RCA }\end{array}$ & $\begin{array}{l}\text { Positive } \\
\text { Negative } \\
\text { Positive }\end{array}$ & $\begin{array}{l}0.45 \\
0.96\end{array}$ & 0.98 & PCI LAD \\
\hline
\end{tabular}

$\mathrm{Cx}$, circumflex artery; LAD, left anterior descending artery; RCA, right coronary artery.

Conclusions Combined CMR and interventional coronary procedures are feasible and well tolerated in an XMR laboratory. This setup has exciting research and clinical applications which should improve knowledge and management of coronary artery disease.

\section{LEFT BUNDLE BRANCH BLOCK AS AN ACTIVATION CRITERION FOR PRIMARY PERCUTANEOUS CORONARY INTERVENTION: WHERE IS THE EVIDENCE?}

doi:10.1136/heartjnl-2012-301877b.26

A J Brown, ${ }^{*}$ M Malone-Lee, L M McCormick, S P Hoole, P M Schofield, N E J West. Papworth Hospital, UK

Background The activation criteria for primary percutaneous coronary intervention (PPCI) includes chest pain in association with either ST-segment elevation (STEMI) or new-onset left bundle branch block (LBBB) on the ECG. However, defining LBBB as new is challenging acutely and the poor specificity of indeterminate chronicity $\mathrm{LBBB}$ may result in unnecessary PPCI activations. Published data are conflicting with regard to the utility of LBBB as a triage criterion for PPCI and subsequent outcomes are undefined.

Methods Consecutive patients attending a single UK tertiary centre for presumed PPCI between September 2008 and December 2010 were included $(n=1328)$. The activation ECG was obtained from the hospital PPCI database, as were demographic data. Outcome data were obtained from notes and national databases. MACE was defined as a composite of mortality and unplanned revascularisation. Two interventionists blinded to patient outcome reviewed the angiographic images and adjudicated if the activation was appropriate.

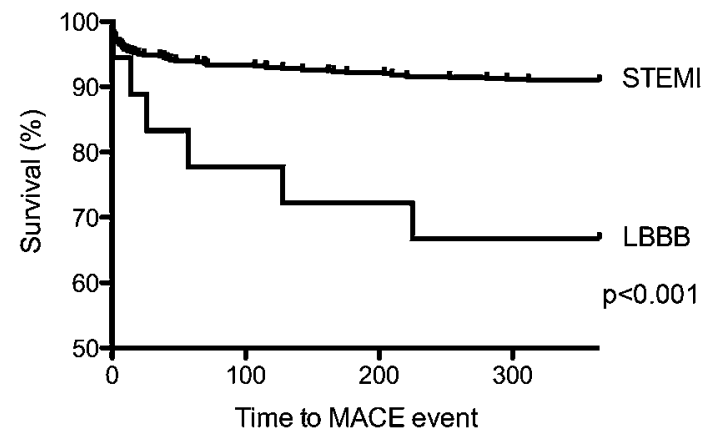

Abstract 026 Figure 1
Results Chest pain with LBBB (LBBB-activation) occurred in 88 patients $(6.6 \%)$ of the PPCI cohort. Comparing LBBB-activations to those with STEMI demonstrated that LBBB-activations were older (mean age $70.3 \pm 12.4$ vs $64.6 \pm 13.4$ years; $\mathrm{p}<0.001$ ) and less likely to be male $(67.0 \%$ vs $76.8 \% ; p=0.004)$. Otherwise, baseline demographics were similar. Eighteen (20.5\%) patients with LBBB had an acute thrombotic coronary occlusion confirmed at angiography and received $\mathrm{PPCI}$. The final adjudicated diagnoses for $\mathrm{LBBB}$-activations were acute coronary syndrome (ACS) (39.8\%), non-ACS cardiac $(28.4 \%)$ and non-cardiac (31.8\%). A history of previous MI $(p=0.002)$ and presence of cardiogenic shock on arrival $(p=0.04)$ were more prevalent in the appropriate LBBB-activations. One-year mortality and MACE were higher for appropriate LBBB-activations than the STEMI activations (27.8\% vs $7.9 \%$; $=0.002$ (Abstract 026 figure 1) and $33.3 \%$ vs $9.1 \%$; $<<0.001$ respectively).

Conclusions Less than half of LBBB-activations had an ACS and, of these, only half had a thrombotic coronary occlusion requiring PPCI. However, LBBB-activations have a significantly worse prognosis and merit urgent referral. Enhanced triage methods are required to correctly identify acute MI requiring PPCI in those with LBBB.

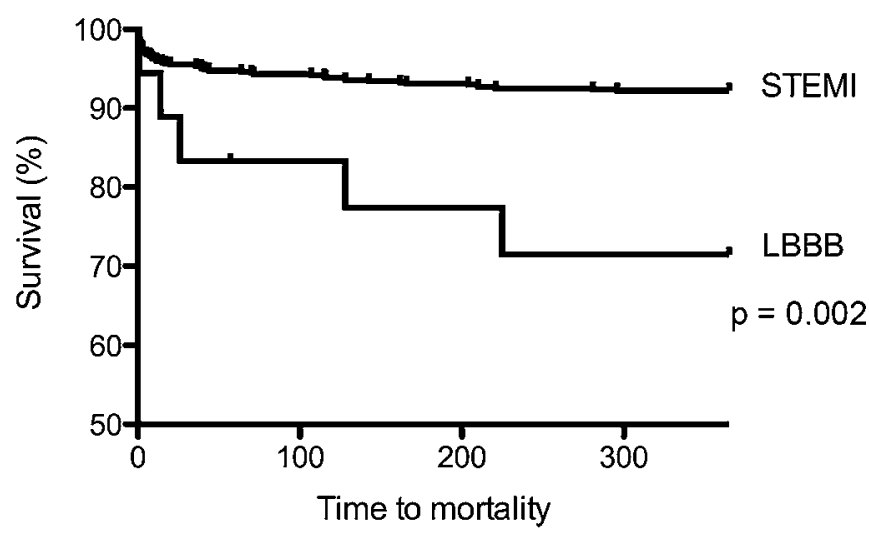

Abstract 026 Figure 2

\section{PERCUTANEOUS CORONARY INTERVENTION IN OCTOGENARIANS: RESULTS FROM A HIGH VOLUME CENTRE}

doi:10.1136/heartjnl-2012-301877b.27

R Showkathali, ${ }^{*}$ E Boston-Griffiths, H Patel, A Ramoutar, J Davies, A Kabir, R Gamma, R Jagathesan, J Sayer, G Clesham, P Kelly, R Aggarwal. The Essex Cardiothoracic Centre, Essex, UK

Aims Octogenarians constitute a fast growing group of patients referred for percutaneous coronary intervention (PCI) for stable angina and acute coronary syndromes (ACS). However, there are limited outcome data for PCI in this group. We evaluated the outcome of PCI in patients aged $\geq 80$ years and compared them with younger patients treated in our centre.

Methods We analysed all patients aged $\geq 80$ years who underwent PCI in our unit between September 2009 and December 2010. Prospectively entered data were obtained from our dedicated cardiac service database system (Philips CVIS). Mortality data were obtained from the summary care record (SCR) database. Follow-up data were obtained from patients' respective district general hospitals and general practitioners' medical records. We defined major bleeding as anyone requiring at-least one unit of red cell transfusion. Results Of the 2931 patients who underwent PCI in our unit during the study period, $401(13.7 \%)$ patients were $\geq 80$ years of age. Out of this $163(40.6 \%)$ had primary PCI (PPCI) for STEMI, 120 (29.9\%) 